\title{
Effect of Spatial Pattern and Nitrogen Scheduling on Yield Attributes, Yield and Harvest Index in Maize (Zea mays L.)
}

\author{
Selvakumar Dharmalingam $^{1 *}$, Velayudham Kumaran ${ }^{2}$ and Thavaprakaash Nallasamy $^{2}$ \\ ${ }^{1}$ Thanthai Roever Institute of Agriculture and Rural Development, \\ Perambalur- 621 115, Tamil Nadu, India \\ ${ }^{2}$ Department of Agronomy, Tamil Nadu Agricultural University, Coimbatore- 641003 , \\ Tamil Nadu, India \\ *Corresponding author
}

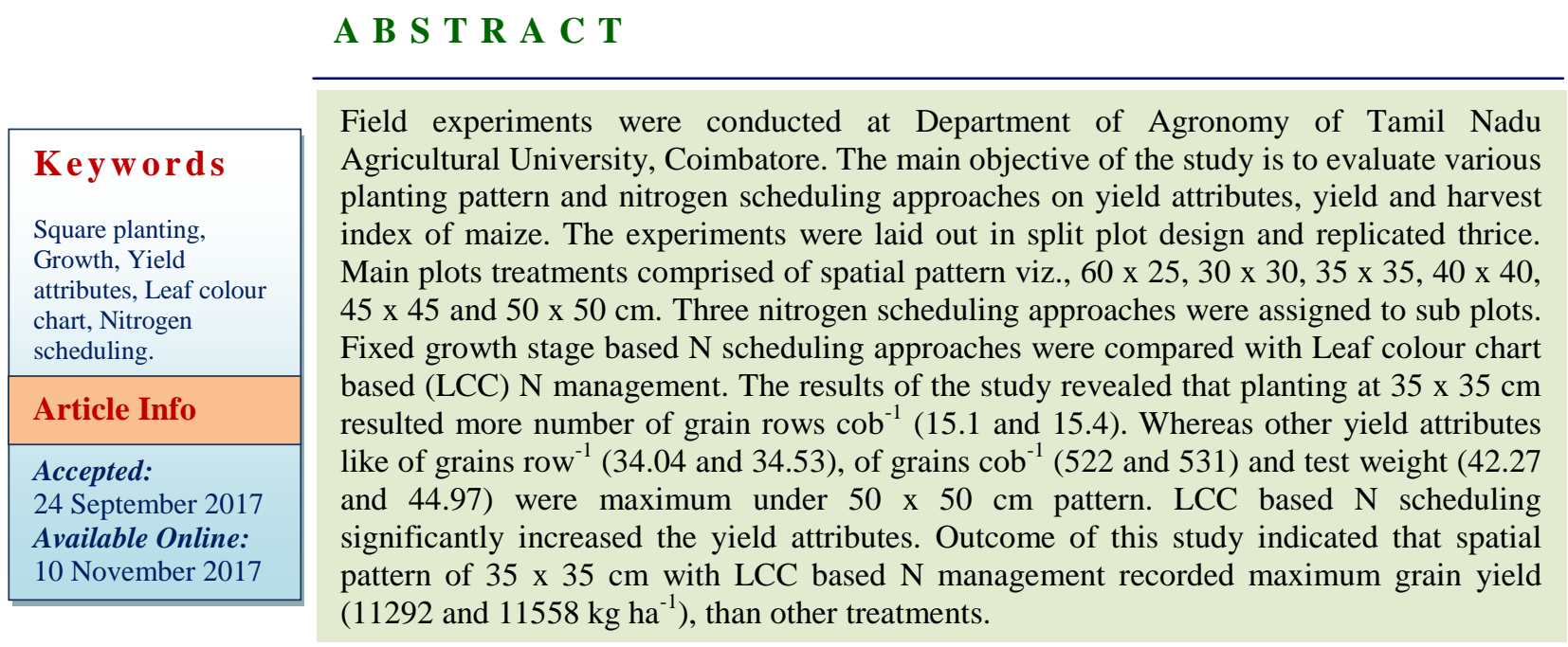

\section{Introduction}

Maize is a miracle crop called as queen of cereals and is grown in more than 166 countries occupying 168 million hectares with production of 854 million tonnes and productivity of $5120 \mathrm{~kg} \mathrm{ha}^{-1}$. In general, maize was cultivated in larger distance between rows than within the same row. Maddonni et al., (2001) have detected that maize leaf orientation in horizontal plane (i.e., leaf azimuth distribution) can react filling empty spaces (e.g., intra-row or inter-row) due to plant spatial arrangement. Grain yield is a function of actual improvement in light interception at silking stage in narrow row spaced plants (Andrade et al., 2002). Plant population/unit land area plays an important role in the radiation use efficiency (RUE) and subsequently the grain yield. The grain yield is also determined by the number of kernels/plant and kernel weight during the grain filling period also substantially increase the grain yield by more translocation of assimilates especially at post silking period and this mostly depends on the intercepted photosynthetically active radiation (IPAR) and RUE (Borras et al., 2003). 
Very few researchers explored the benefits of square planting in maize. At flowering stage, corn grown under square pattern intercepted more PAR than rectangular arrangement (Acciaresi and Chidichimo, 2007) and also better resource utilization and lesser weed competition leads to higher grain yield. The productivity of maize is determined by several factors including nitrogen factor. Traditionally, $\mathrm{N}$ fertilizers have been applied uniformly across entire field while ignoring spatial variation in crop $\mathrm{N}$ needs within crop fields (Khosla et al., 2010).

This resulted too little $\mathrm{N}$ reduces yields while too much $\mathrm{N}$ reduces nitrogen use efficiency. Application of higher level of $\mathrm{N}$ fertilizer is very common among Indian farmers, who attribute maize crop greenness and growth response to $\mathrm{N}$ application. Chlorophyll meter is expensive (US\$1200-1800/unit) to be owned by farmers in developing countries which restricts its wide spread use by farmers. The leaf colour chart was developed for rice and is also suitable for maize as indicated by spectral reflectance measurements performed on rice and maize leaves (Witt et al., 2005).

LCC proves to be an effective tool in detecting the maize additional $\mathrm{N}$ need, giving higher yields and increased profit compared with fixed rates (Pasuquin et al., 2012). There is need to investigate $\mathrm{N}$ management with tools like LCC for site specific nitrogen management in maize.

Information on the square planting pattern to explore the available resources and suitable $\mathrm{N}$ scheduling practices to maximize maize yield is meagre. Hence, this study has been contemplated on hybrid maize with various square crop geometry levels and $\mathrm{N}$ scheduling approaches with the following objectives include studying the effect of spatial pattern on yield attributes; to study the influence of spatial pattern on yield; and to evaluate nitrogen approaches on yield attributes.

\section{Materials and Methods}

The average maximum and the minimum temperature were $30.2^{\circ} \mathrm{C}$ and $21.1^{\circ} \mathrm{C}$ and $31.0^{\circ} \mathrm{C}$ and $21.5^{\circ} \mathrm{C}$, respectively. The total rainfall received during the cropping period was $84.6 \mathrm{~mm}$ and $202.8 \mathrm{~mm}$, the average relative humidity at $0722 \mathrm{hrs}$ and $1422 \mathrm{hrs}$ were 89.7 per cent, 57.2 per cent and 86.0 per cent and 50.7 per cent respectively, with an average bright sunshine hour of 6.3 and 6.5 hours with an evaporation of 3.9 and $4.8 \mathrm{~mm}$ day-1. The mean solar radiation recorded was 356.3 and $355.9 \mathrm{Cal} \mathrm{cm}^{-2}$ day $^{-1}$, respectively. The soil of the experimental site was clay loam in texture belonging to Irugur series and taxonomically known as Typic Ustropepts under USDA classification. Field experiments were laid out in split plot design and treatments were replicated thrice. Maize hybrid, NK 6240 was used as test crop. Main plot treatments were viz., $\mathrm{M}_{1}-60 \times 25, \mathrm{M}_{2}-30$ x $30, \mathrm{M}_{3-} 35$ x $35, \mathrm{M}_{4}-40$ x 40, 45 x 45 and $50 \times 50 \mathrm{~cm}$. Nitrogen scheduling approaches of Recommended dose of nitrogen (RDN) @ $150 \mathrm{~kg} \mathrm{ha}^{-1}$ in 3 splits as 25,50 and 25 per cent at basal, 25 and 45 DAS, N2- RDN@ $150 \mathrm{~kg} \mathrm{ha}^{-1}$ in 4 splits each 25 per cent at basal, 15, 30 and 45 DAS, Leaf colour chart (LCC) based nitrogen scheduling (whenever LCC critical value falls below 5, top dressing of $\mathrm{N} @ 30 \mathrm{~kg} \mathrm{ha}^{-1}$ ) were imposed. The recommended entire dose $\left(75 \mathrm{~kg} \mathrm{ha}^{-1}\right)$ of P2O5 was applied basally. The $\mathrm{K}_{2} \mathrm{O}(75 \mathrm{~kg}$ $\mathrm{ha}^{-1}$ ) was applied in two equal split doses viz., basal and with first top dressing of nitrogen.

The mean of grain rows $\mathrm{cob}^{-1}$, of grains row $^{-1}$, of grains $\mathrm{cob}^{-1}$ was counted from the cobs obtained from five sample plants and expressed in numbers $\mathrm{cob}^{-1}$. The randomly selected 100 grains were air dried for each treatment (in three replications) and weight was recorded. The average was arrived and expressed in $\mathrm{g}$. The cobs of the sample plants of the net plot area of each treatment were shelled separately. The grain weight to the 
entire cob weight was computed and the mean for each treatment was expressed in percentage. The cobs from the net plot were harvested separately. The cobs were sun dried, shelled, cleaned and grain yield was recorded for individual treatment at 14 per cent seed moisture and expressed in $\mathrm{kg} \mathrm{ha}^{-1}$.

After the harvest of cobs, the stover in the net plot area were cut close to the ground level and left in the field for three days for sun drying. After drying, weight of stover from each plot was recorded and expressed in $\mathrm{kg}$ $\mathrm{ha}^{-1}$. Harvest Index was calculated from the dry weight of grain and total dry weight using the formula of Yoshida et al., (1972) as given below.

$$
\mathrm{HI}=\frac{\text { Economic yield }\left(\mathrm{kg} \mathrm{ha}^{-1}\right)}{\text { Biological yield }\left(\mathrm{kg} \mathrm{ha}^{-1}\right)}
$$

The data collected were statistically analyzed as suggested by Gomez and Gomez (2010).

\section{Results and Discussion}

Maize crop planted at $35 \times 35 \mathrm{~cm}$ registered more No. of rows $\operatorname{cob}^{-1}$ (15.1 and 15.4) during 2011 and 2012, respectively. Whereas, Spatial pattern of $50 \times 50 \mathrm{~cm}$ recorded lucidly more of grains row $^{-1}$ (34.04 and 34.53) and of grains $\operatorname{cob}^{-1}$ (522 and 531) than narrow pattern. Similarly, hundred grains weight also more (42.27 and $44.97 \mathrm{~g}$ ) under this pattern. Nitrogen scheduling also significantly influenced the No. of rows $\mathrm{cob}^{-1}$ and higher values (14.7 and 15.0) were registered under LCC based $\mathrm{N}$ scheduling than other treatments. Similarly, N scheduling based on LCC recorded more of grains row $^{-1}$ (32.03 and 32.51), of grains $\operatorname{cob}^{-1}$ (479 and 496) than other treatments.

The test weight of maize grain was also maximum (41.45 and $43.47 \mathrm{~g}$ ) under this $\mathrm{N}$ management strategy. Spatial pattern and N scheduling treatments had no significant effect on shelling percentage of maize cob. Interaction effect was not observed between spatial pattern and $\mathrm{N}$ scheduling with respect to yield attributes (Table 1).

Among the different spatial treatments, maize planted at $35 \times 35 \mathrm{~cm}$ resulted in achieving higher maize grain yield (10337 and $10029 \mathrm{~kg}$ $\mathrm{ha}^{-1}$ ) during 2011 and 2012, respectively and was superior over others (Tables 2 and 3). Maize crop nourished through LCC based N application recorded significantly higher grain yield (9253 and $9378 \mathrm{~kg} \mathrm{ha}^{-1}$ ) and it was significantly differed from the other treatments.

The interaction effect observed between crop geometry and $\mathrm{N}$ scheduling approaches was significant. The combination of LCC based $\mathrm{N}$ management and planted at $35 \times 35 \mathrm{~cm}$ was found to record higher grain yields (11292 and $11558 \mathrm{~kg} \mathrm{ha}^{-1}$ ) than other combinations. Spatial pattern and $\mathrm{N}$ scheduling approaches significantly influenced the stover yield as that of grain yield. Higher stover yield (20666 and $20439 \mathrm{~kg} \mathrm{ha}^{-1}$ ) was recorded under crop geometry treatment of $30 \times 30 \mathrm{~cm}$ and it was significantly differed from other treatments. Marked difference of maize stover yield was manifested due to nitrogen scheduling methods and higher yield (16778 and 16270 $\mathrm{kg} \mathrm{ha}{ }^{-1}$ ) realized under LCC based $\mathrm{N}$ management.

The mean data pertaining to harvest index using grain and stover yields are shown in Tables 2 and 3. Higher HI value of 0.37 was recorded under crop geometry of $35 \times 35 \mathrm{~cm}$ and it was significantly different from other treatments. Maize crop supplied with LCC based $\mathrm{N}$ resulted in achieving a higher $\mathrm{HI}$ $(0.35$ and 0.36$)$ than others. 
Table.1 Effect of spatial pattern and nitrogen scheduling on yield attributes of maize

\begin{tabular}{|c|c|c|c|c|c|c|c|c|c|c|}
\hline \multirow{2}{*}{ Treatments } & \multicolumn{2}{|c|}{ No. of grain rows cob $^{-1}$} & \multicolumn{2}{|c|}{ No. of grains row ${ }^{-1}$} & \multicolumn{2}{|c|}{ No. of grains $\operatorname{cob}^{-1}$} & \multicolumn{2}{|c|}{ Shelling percentage } & \multicolumn{2}{|c|}{100 grain weight $(\mathrm{g})$} \\
\hline & 2011 & 2012 & 2011 & 2012 & 2011 & 2012 & 2011 & 2012 & 2011 & 2012 \\
\hline \multicolumn{11}{|l|}{ Main plot: Spatial pattern } \\
\hline$M_{1}-60 \times 25 \mathrm{~cm}$ & 14.7 & 14.9 & 29.43 & 29.86 & 428 & 444 & 81.2 & 83.4 & 37.85 & 39.49 \\
\hline $\mathbf{M}_{2}-30 \times 30 \mathrm{~cm}$ & 13.5 & 13.7 & 27.33 & 27.71 & 382 & 405 & 80.3 & 82.3 & 36.65 & 38.89 \\
\hline $\mathbf{M}_{3}-35 \times 35 \mathrm{~cm}$ & 15.1 & 15.4 & 30.16 & 30.63 & 442 & 463 & 81.4 & 82.2 & 39.40 & 41.26 \\
\hline $\mathbf{M}_{4}-40 \times 40 \mathrm{~cm}$ & 14.6 & 14.8 & 31.70 & 32.18 & 477 & 491 & 81.1 & 81.8 & 40.97 & 43.04 \\
\hline $\mathbf{M}_{5}-45 \times 45 \mathrm{~cm}$ & 13.8 & 14.0 & 33.70 & 34.20 & 501 & 513 & 79.5 & 79.7 & 41.95 & 43.57 \\
\hline $\mathbf{M}_{6}-50 \times 50 \mathrm{~cm}$ & 13.7 & 13.9 & 34.04 & 34.53 & 522 & 531 & 79.1 & 80.1 & 42.27 & 44.97 \\
\hline SEm & 0.3 & 0.3 & 0.88 & 0.89 & 11 & 12 & 2.3 & 1.4 & 1.14 & 1.24 \\
\hline C.D $(\mathrm{P}=0.05)$ & 0.8 & 0.7 & 1.97 & 2.00 & 27 & 27 & NS & NS & 2.55 & 2.76 \\
\hline \multicolumn{11}{|c|}{ Sub plot: Nitrogen scheduling } \\
\hline $\mathbf{N}_{1}$ & 14.0 & 14.2 & 30.19 & 30.63 & 438 & 455 & 79.9 & 81.3 & 38.76 & 41.31 \\
\hline $\mathbf{N}_{2}$ & 14.1 & 14.3 & 30.95 & 31.41 & 458 & 473 & 80.4 & 81.8 & 39.34 & 40.83 \\
\hline $\mathbf{N}_{3}$ & 14.7 & 15.0 & 32.03 & 32.51 & 479 & 496 & 80.9 & 81.6 & 41.45 & 43.47 \\
\hline SEm & 0.2 & 0.3 & 0.51 & 0.52 & 8.0 & 8 & 1.3 & 0.8 & 0.66 & 0.85 \\
\hline C.D $(\mathrm{P}=0.05)$ & 0.5 & 0.6 & 1.06 & 1.08 & 17 & 17 & NS & NS & 1.36 & 1.76 \\
\hline Interaction $(\mathrm{M} \times \mathrm{N})$ & NS & NS & NS & NS & NS & NS & NS & NS & NS & NS \\
\hline
\end{tabular}

$\mathrm{N}_{1}$ - Recommended dose of nitrogen (RDN) @ $150 \mathrm{~kg} \mathrm{ha}^{-1}$ in 3 splits; $\mathrm{N}_{2}$ - RDN @ $150 \mathrm{~kg}$ ha ${ }^{-1}$ in 4 splits, $\mathrm{N}_{3}$ - LCC based N application

Table.2 Grain yield $\left(\mathrm{kg} \mathrm{ha}^{-1}\right)$, Stover yield $\left(\mathrm{kg} \mathrm{ha}^{-1}\right)$ and Harvest index of maize as influenced by different spatial pattern and nitrogen scheduling approaches during 2011

\begin{tabular}{|c|c|c|c|c|c|c|c|c|c|c|c|c|}
\hline \multirow{2}{*}{ Treatments } & \multicolumn{4}{|c|}{ Grain yield $\left(\mathrm{kg} \mathrm{ha}^{-1}\right)$} & \multicolumn{4}{|c|}{ Stover yield $\left(\mathrm{kg} \mathrm{ha}^{-1}\right)$} & \multicolumn{4}{|c|}{ Harvest index } \\
\hline & $\mathbf{N}_{1}$ & $\mathbf{N}_{2}$ & $\mathbf{N}_{3}$ & Mean & $\mathbf{N}_{1}$ & $\mathbf{N}_{2}$ & $\mathbf{N}_{3}$ & Mean & $\mathbf{N}_{1}$ & $\mathbf{N}_{2}$ & $\mathbf{N}_{3}$ & Mean \\
\hline$M_{1}-60 \times 25 \mathrm{~cm}$ & 9278 & 9875 & 10829 & 9994 & 18333 & 17133 & 18333 & 17933 & 0.33 & 0.36 & 0.37 & 0.35 \\
\hline $\mathbf{M}_{2}-30 \times 30 \mathrm{~cm}$ & 7510 & 9097 & 8807 & 8471 & 20666 & 19333 & 22000 & 20666 & 0.26 & 0.32 & 0.28 & 0.29 \\
\hline $\mathbf{M}_{3}-35 \times 35 \mathrm{~cm}$ & 9544 & 10175 & 11292 & 10337 & 17000 & 16666 & 17668 & 17111 & 0.36 & 0.38 & 0.39 & 0.37 \\
\hline $\mathbf{M}_{4}-40 \times 40 \mathrm{~cm}$ & 7900 & 8462 & 9534 & 8632 & 15333 & 15333 & 15668 & 15445 & 0.34 & 0.35 & 0.38 & 0.35 \\
\hline $\mathbf{M}_{5}-45 \times 45 \mathrm{~cm}$ & 7779 & 6604 & 7855 & 7413 & 12000 & 12333 & 14335 & 12889 & 0.39 & 0.34 & 0.35 & 0.36 \\
\hline $\mathbf{M}_{6}-50 \times 50 \mathrm{~cm}$ & 6024 & 6107 & 7202 & 6444 & 11833 & 12000 & 12666 & 12166 & 0.33 & 0.33 & 0.36 & 0.34 \\
\hline \multirow[t]{2}{*}{ Mean } & 8006 & 8387 & 9253 & & 15861 & 15466 & 16778 & & 0.33 & 0.35 & 0.35 & \\
\hline & $\mathbf{M}$ & $\mathbf{N}$ & $\mathbf{M}$ at $\mathbf{N}$ & $\mathrm{N}$ at $\mathrm{M}$ & $\mathbf{M}$ & $\mathbf{N}$ & $\mathbf{M}$ at $\mathbf{N}$ & $\mathrm{N}$ at $\mathrm{M}$ & $\mathbf{M}$ & $\mathbf{N}$ & $\mathbf{M}$ at $\mathbf{N}$ & $\mathrm{N}$ at $\mathrm{M}$ \\
\hline SEm & 376 & 191 & 536 & 467 & 577 & 311 & 848 & 761 & 0.004 & 0.002 & 0.007 & 0.006 \\
\hline $\mathrm{CD}(\mathrm{P}=0.05)$ & 837 & 394 & 1149 & 965 & 1286 & 642 & NS & NS & 0.011 & 0.005 & 0.015 & 0.013 \\
\hline
\end{tabular}

$\mathrm{N}_{1}$ - Recommended dose of nitrogen (RDN) @ $150 \mathrm{~kg} \mathrm{ha}^{-1}$ in 3 splits, $\mathrm{N}_{2}$ - RDN @ $150 \mathrm{~kg} \mathrm{ha}{ }^{-1}$ in 4 splits, $\mathrm{N}_{3}$ - LCC based N application 
Table.3 Grain yield $\left(\mathrm{kg} \mathrm{ha}^{-1}\right)$, Stover yield $\left(\mathrm{kg} \mathrm{ha}^{-1}\right)$ and Harvest index of maize as influenced by different spatial pattern and nitrogen scheduling approaches during 2012

\begin{tabular}{|c|c|c|c|c|c|c|c|c|c|c|c|c|}
\hline \multirow{2}{*}{ Treatments } & \multicolumn{4}{|c|}{ Grain yield $\left(\mathrm{kg} \mathrm{ha}^{-1}\right)$} & \multicolumn{4}{|c|}{ Stover yield $\left(\mathrm{kg} \mathrm{ha}^{-1}\right)$} & \multicolumn{4}{|c|}{ Harvest index } \\
\hline & $\mathbf{N}_{1}$ & $\mathbf{N}_{2}$ & $\mathbf{N}_{3}$ & Mean & $\mathbf{N}_{1}$ & $\mathbf{N}_{2}$ & $\mathbf{N}_{3}$ & Mean & $\mathbf{N}_{1}$ & $\mathbf{N}_{2}$ & $\mathbf{N}_{3}$ & Mean \\
\hline $\mathbf{M}_{1}-60 \times 25 \mathrm{~cm}$ & 8983 & 8821 & 11084 & 9629 & 15820 & 16382 & 17330 & 16511 & 0.36 & 0.35 & 0.39 & 0.36 \\
\hline $\mathbf{M}_{2}-30 \times 30 \mathrm{~cm}$ & 7936 & 7815 & 8383 & 8045 & 18202 & 20618 & 22497 & 20439 & 0.30 & 0.27 & 0.27 & 0.28 \\
\hline $\mathbf{M}_{3}-35 \times 35 \mathrm{~cm}$ & 8649 & 9879 & 11558 & 10029 & 17139 & 16476 & 17639 & 17084 & 0.33 & 0.37 & 0.39 & 0.36 \\
\hline $\mathbf{M}_{4}-40 \times 40 \mathrm{~cm}$ & 7185 & 8259 & 9379 & 8274 & 13214 & 12941 & 14158 & 13438 & 0.35 & 0.39 & 0.40 & 0.38 \\
\hline $\mathbf{M}_{5}-45 \times 45 \mathrm{~cm}$ & 7407 & 7396 & 8123 & 7642 & 13299 & 13370 & 13552 & 13407 & 0.35 & 0.35 & 0.37 & 0.36 \\
\hline $\mathbf{M}_{6}-50 \times 50 \mathrm{~cm}$ & 6628 & 7134 & 7740 & 7167 & 10830 & 11555 & 12445 & 11610 & 0.38 & 0.38 & 0.38 & 0.38 \\
\hline \multirow[t]{2}{*}{ Mean } & 7798 & 8217 & 9378 & & 14751 & 15224 & 16270 & & 0.34 & 0.35 & 0.36 & \\
\hline & $\mathbf{M}$ & $\mathbf{N}$ & $\mathbf{M}$ at $\mathbf{N}$ & $\mathbf{N}$ at $\mathbf{M}$ & $\mathbf{M}$ & $\mathbf{N}$ & M at $\mathbf{N}$ & $\mathbf{N}$ at $\mathbf{M}$ & $\mathbf{M}$ & $\mathbf{N}$ & $\mathbf{M}$ at $\mathbf{N}$ & $\mathrm{N}$ at $\mathrm{M}$ \\
\hline SEm & 462 & 205 & 617 & 501 & 598 & 393 & 987 & 962 & 0.015 & 0.007 & 0.021 & 0.017 \\
\hline $\mathrm{CD}(\mathrm{P}=\mathbf{0 . 0 5})$ & 1029 & 422 & 1330 & 1035 & 1333 & 811 & NS & NS & 0.034 & 0.014 & 0.045 & 0.035 \\
\hline
\end{tabular}

$\mathrm{N}_{1}$ - Recommended dose of nitrogen (RDN) @ $150 \mathrm{~kg} \mathrm{ha}^{-1}$ in 3 splits

$\mathrm{N}_{2}$ - RDN @ $150 \mathrm{~kg} \mathrm{ha}^{-1}$ in 4 splits

$\mathrm{N}_{3}$ - LCC based $\mathrm{N}$ application 


\section{Yield attributes}

The spacing of $35 \times 35 \mathrm{~cm}$ found to record more No. of grain rows $\operatorname{cob}^{-1}$ compared to rest of the spacing levels on contrary, closer spacing of $30 \times 30 \mathrm{~cm}$ recorded minimum number of grain rows $\operatorname{cob}^{-1}$. This might be due to closer spacing reduced ear shoot growth which resulted fewer spikelet primordia transformed into functional florets by the time of flowering. The limited carbon and nitrogen supply to the ear stimulates young kernel abortion immediately after fertilization (Sangoi, 2001). Similar results were reported by Abuzar et al., (2011) in maize. The No. of grains row $^{-1}$, No. of grains $\mathrm{cob}^{-1}$ and hundred grain weight were significantly higher in $50 \times 50 \mathrm{~cm}$ patter than other treatments. This could be attributed to lesser competition among plants within rows for light, water and nutrients which might have enhanced the availability of carbohydrate for the plant to set more grains ear $^{-1}$. The results are in agreement with Hamayun (2003).

The LCC based $\mathrm{N}$ scheduling recorded more No. of grain rows $\mathrm{cob}^{-1}$, No. of grains $\operatorname{row}^{-1}$, No. of grains $\operatorname{cob}^{-1}$ and hundred grain weight compared to other recommended $\mathrm{N}$ scheduling practices. This was mainly due to increased $\mathrm{N}$ availability under LCC based application might have reduced grain abortion. This also could be attributed to increased availability of nitrogen from early to grain filling stages which increased the content and uptake of nitrogen which in turn increased the yield attributes. This is in corroborates with the findings of Singh (2010) in maize.

\section{Yield}

In the present study, higher grain yield was obtained under $35 \times 35 \mathrm{~cm}$ spacing and it was 3.4 and 4.2 per cent higher over rectangular planting during 2011 and 2012, respectively. The increased grain yield under square pattern was primarily due to decreased intra-plant competition for resources. This decreased competition lead to more uniform root and leaf distribution that promote more effective utilization of light (Sharratt and Mc Williams, 2005), particularly increased intercepted photosynthetically active radiation (IPAR) at flowering stage (Acciaresi and Chidichimo, 2007) and radiation interception during grain filling process (Andrade et al., 2002). Stover yield was higher at closer spacing of $30 \times 30$ $\mathrm{cm}$ and it was 15.2 and 23.8 per cent higher than $60 \times 25 \mathrm{~cm}$. The stover yield was drastically reduced under wider spacing of 50 $\times 50 \mathrm{~cm}$. The higher number of plants unit area $^{-1}$ contributed higher stover yield. Widdicombe and Thelen (2002) also observed that an increase in planting density increased the fodder yield linearly. This is in confirmity with the findings of Kumar (2009) and Shakarami and Rafiee (2009) in maize.The higher $\mathrm{HI}$ at $35 \times 35 \mathrm{~cm}$ indicates that optimum density per unit area is efficiently converted the biological yield to economic yield.

Both the years, LCC based $\mathrm{N}$ scheduling strikingly increased grain yield of maize. The percentage increase of $\mathrm{N}_{3}$ over $\mathrm{N}_{2}$ (RDN @ $150 \mathrm{~kg} \mathrm{ha}^{-1}$ in 4 splits) was 10.3 and 14.1 and it was 15.6 and 20.3 per cent superior over $\mathrm{N}_{1}$ (RDN @ $150 \mathrm{~kg} \mathrm{ha}^{-1}$ in 3 splits) during 2011 and 2012, respectively. The increased grain yield might be due to LCC based $\mathrm{N}$ application matched crop $\mathrm{N}$ demand which led to increased $\mathrm{N}$ uptake and improved the efficiency of applied N. The LCC treatment received higher quantity of $\mathrm{N}$ up to $180 \mathrm{~kg}$ $\mathrm{ha}^{-1}$ based on LCC threshold value. Other favourable conditions under LCC threshold value 5 coincided with critical growth stages like $12^{\text {th }}$ leaf stage $(28 \mathrm{DAS}), 15^{\text {th }}$ leaf stage (35 DAS), $18^{\text {th }}$ leaf stage (42 DAS) tasseling (49 DAS) and silking (56 DAS) stages, 
respectively. The LCC based $\mathrm{N}$ application of $\mathrm{N}$ upto silking improved the vegetative and reproductive growth of maize and increased cob bearing plants. It is possible that late $\mathrm{N}$ application upto silking could provide an additional source for elevated rate of photosynthesis and transport of photoassimilates during grain filling that resulted in the higher grain yield. This is in accordance with the findings of Pasuquin et al.,(2012) in maize. As that of grain, the stover yield was also higher with LCC based $\mathrm{N}$ scheduling. This is in conformity with the findings of Balaji and Jawahar (2007) reported that LCC5 based $\mathrm{N}$ application increased straw yield.

Among the different combinations evaluated, spacing of $35 \times 35 \mathrm{~cm}$ and maize crop nourished with $\mathrm{N}$ based on LCC value produced higher grain yield than other combinations. This corroborates with the findings of Biradar et al., (2012) in maize. The increased grain yield might be due to increase in $\mathrm{N}$ accumulation associated with radiation interception and increased volume of soil made available for exploration by each plant than conventional spacing resulted in higher grain yield. Based on the experimental results it was concluded that wider spacing of $50 \mathrm{x}$ $50 \mathrm{~cm}$ favoured yield attributes. Even though wider planting realized higher yield attributes the square planting of $35 \times 35 \mathrm{~cm}$ found to be optimum for maximizing the yield. The LCC based $\mathrm{N}$ scheduling outperformed conventional approach in terms of yield and yield attributes. Integrated approach of $35 \mathrm{x}$ $35 \mathrm{~cm}$ with LCC based $\mathrm{N}$ scheduling could sustain the productivity of maize and also it could avoid excess application of $\mathrm{N}$ and protect the environment.

\section{References}

Abuzar, M.R., G.U. Sadozai, M.S. Baloch, A.A. Baloch, I.H. Shah, T. Javaid and N. Hussain. 2011. Effect of plant population densities on yield of maize Journal of Animal Plant Science, 21(4): 692-695.

Acciaresi, H.A. and H.O. Chidichimo. 2007. Spatial pattern effect on corn (Zea mays) weeds competition in the humid pampas of Argentina. International Journal of Pest Management, 53(3): 195206.

Andrade, F.H., P. Calvino, A. Cirilo and P. Barbieri. 2002. Yield responses to narrow rows depend on increased radiation interception. Agronomy Journal, 94: 975-980.

Balaji, T. and D. Jawahar. 2007. Comparison of LCC and SPAD methods for assessing nitrogen requirement of rice. Crop Research, 33(1, 2 \&3): 30-34.

Biradar, D.P., Y.R. Aladakatti, D. Shivamurthy, T. Satyanarayana and K. Majumdar. 2012. Managing fertilizer nitrogen to optimize yield and economics of maize-wheat cropping system in northern Karnataka. Better crops-South Asia, 6(1): 19-21.

Borras, L., G.A. Maddonni and M.E. Otegui. 2003. Leaf senescence in maize hybrids: Plant population, row spacing and kernel set effects. Field Crops Research, 82: 13-26.

Gomez, K.A. and A.A. Gomez. 2010. Statistical Procedures for Agricultural Research. $2^{\text {nd }}$ Edn. John Wiley and Sons, New York, USA. p.680.

Hamayun, M. 2003. Effect of spacing and weed free periods on the productivity of maize (Zea mays). Pakistan Journal of Weed Science Research, 9(3\&4):179184.

Khosla, R., R.M. Westfall, R.M. Reich, J.S. Mahal and W.J. Gangloff. 2010. Spatial variation and site-specific management. In: Geostatistical applications for precision agriculture. Oliver, M.A (Ed.). Pp. 195-219.

Kumar, A. 2009. Influence of varying plant 
population and nitrogen levels on growth, yield, economics and nitrogen use efficiency of pop corn (Zea mays everta Sturt). Crop Research, 37(1, 2\&3): 19-23.

Maddonni, G.A., M. Chelle, J.L. Drouet and B. Andrieu. 2001. Light interception of contrasting azimuth canopies under square and rectangular plant spatial distributions: Simulations and crop measurements. Field Crops Research, 70: 1-13.

Pasuquin, J.M., S. Saenong, P.S. Tan, C. Witt and M.J. Fisher. 2012. Evaluating N management strategies for hybrid maize in Southeast Asia. Field Crops Research, 134: 153-157.

Sangoi, L. 2001. Understanding plant density effects on maize growth and development: An important issue to maximize grain yield. Cienica Rural, 31 (1): 159-168.

Shakarami, G. and M. Rafiee. 2009. Response of Corn (Zea mays L.) to planting pattern and density in Iran. American-
Eurasian Journal of Agriculture and Environmental Science, 5 (1): 69-73.

Sharratt, B.S. and D.A. Mc Williams. 2005. Microclimatic and rooting characteristics of narrow row versus conventional row corn. Agronomy Journal, 97:1129-1135.

Singh, D. 2010. Impact of scheduling nitrogen on productivity of single cross maize (Zea mays) hybrids. Indian Journal Agricultural Science, 80(7): 649-651.

Widdicombe, W.D. and K.D. Thelen. 2002. Row width and plant density effects on corn grain production in the northern Corn Belt. Agronomy Journal, 94: 1020-1023.

Witt, C., J.M.C.A. Pasuquin, R. Mutters and R.J. Buresh. 2005. New leaf color chart for effective nitrogen management in rice. Better Crops-Southeast Asia, 89 (1): 3639.

Yoshida, S.D.A., Forno, J.H. Cock and K.A. Gomez. 1972. Laboratory manual for physiological studies of Rice. Int. Rice. Res. Instt. Los Banos, Phillippines. p. 70.

\section{How to cite this article:}

Selvakumar Dharmalingam, Velayudham Kumaran and Thavaprakaash Nallasamy. 2017. Effect of Spatial Pattern and Nitrogen Scheduling on Yield Attributes, Yield and Harvest Index in Maize (Zea mays L.). Int.J.Curr.Microbiol.App.Sci. 6(11): 3263-3270. doi: https://doi.org/10.20546/ijcmas.2017.611.382 